\title{
EFFICACY OF AN ORAL HEALTH PROMOTION PROGRAM FOR INFANTS IN THE PUBLIC SECTOR
}

\author{
EFICÁCIA DE UM PROGRAMA DE PROMOÇÃO DE SAÚDE BUCAL \\ EM BEBÊS NO SERVIÇO PÚBLICO
}

Marina de Lourdes Calvo FRACASSO ${ }^{1}$, Daniela RIOS${ }^{2}$, Maria Gisette Arias PROVENZANO ${ }^{3}$, Suzana GOYA ${ }^{4}$

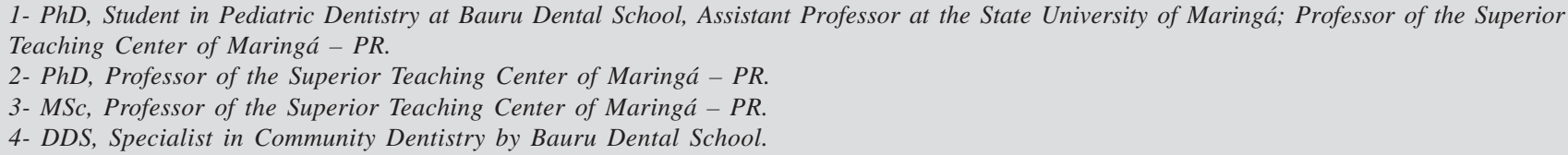

Received: May 20, 2005 - Modification: July 1, 2005 - Accepted: October 03, 2005

\begin{abstract}
$T$

Lhis study compared the caries index (dmft), presence of sucking habits and facial alterations in children attended by the preventive program for infants and children assisted by spontaneous demand, at the same age, at the public sector of Maringá, PR. A total of 100 children were evaluated (1-6 years), who were divided into 2 groups: GI - children attended by the infant program with educational and preventive care and bimonthly follow-up, since the $1^{\text {st }}$ year of age; GII - children assisted for conventional treatment (preventive and restorative) according to the needs, and follow-up as requested by the parents. Data collection was performed by interview with the parents and clinical examination for evaluation of the dmft and facial alterations. Analysis of data (Mann-Whitney test for dmft comparison and chi-square test for all other comparisons) demonstrated a significant difference $(\mathrm{p}<0.05)$ in relation to the dmft index (GI: 0.2; GII: 3.0), percentage of caries-free children (GI: $88 \%$; GII: 57\%) and non-nutritive sucking habits (GI: 47\%; GII: 75\%). The breastfeeding and bottle utilization practices were similar for both groups. Facial alterations were more frequently observed ( $<<0.05)$ in GII (48\%) than GI (8.4\%), especially for the variables $(\mathrm{p}<0.05)$ high arched palate (GI: 10.2\%; GII: 35.4\%), anterior open bite (GI: 14.2\%; GII: 35.4\%) and mouth breathing (GI: 6.1\%; GII: $29.1 \%)$. It was concluded that the infant program is more effective than the spontaneous demand program, reaching the goal of oral health maintenance in the child population.

Uniterms: Oral health; Infant; Public sector; Dental caries; Malocclusions.
\end{abstract}

\begin{abstract}
RESUMO
Q

objetivo do trabalho foi comparar o índice de cárie (ceo), presença de hábitos de sucção e alterações faciais em crianças atendidas no programa de atendimento preventivo a bebês, com crianças atendidas por demanda espontânea, na mesma idade, no serviço público de Maringá-PR. Foram avaliadas 100 crianças (1-5 anos), divididas em 2 grupos: GI-crianças atendidas no programa de bebês com atendimento educativo-preventivo e retornos bimestrais, desde o $1^{\circ}$ ano de vida; GII-crianças atendidas para tratamento convencional (preventivo e curativo) de acordo com a necessidade, sendo o retorno responsabilidade dos familiares. A coleta dos dados foi realizada por meio de entrevista com os pais e através de exame clínico, para avaliação do ceo e alterações faciais. A análise dos dados (Teste de Mann-Whitney para comparações de ceo e teste qui-quadrado para todas outras comparações) mostrou diferença significante $(\mathrm{p}<0,05)$ em relação ao índice ceo (GI: 0,2; GII:3,0), componente livre de cárie (GI:88\%; GII:57\%) e hábitos de sucção não nutritiva (GI:47\%; GII:75\%). As práticas de amamentação e uso da mamadeira foram semelhantes nos grupos. Constatou-se maior presença de alterações faciais $(p<0,05)$ no GII $(48 \%)$ do que no GI $(8,4 \%)$, destacando-se as variáveis ( $\mathrm{p}<0,05)$ palato ogival (GI: 10,2\%; GII:35,4\%), mordida aberta anterior (GI:14,2\%; GII:35,4\%) e respiração bucal (GI: 6,1\%; GII: 29,1\%). Concluiu-se que o programa de atendimento a bebês é mais efetivo que o atendimento de demanda espontânea, cumprindo o objetivo de manutenção da saúde bucal na população infantil.

Unitermos: Saúde bucal; Bebê; Serviço público; Cárie dentária; Maloclusões.
\end{abstract}




\section{INTRODUCTION}

The early childhood may be regarded as the most important period for the future of oral health, since during this stage the children's teeth erupt, are colonized by bacteria, and there is establishment of the diet and hygiene habits that will define the oral health conditions of the individual ${ }^{2}$. Thus, the early care, by dentistry for infants, whose goal is to provide ideal conditions for proper cranial-facial development, plays an important role for oral health prevention and promotion ${ }^{18}$.

The American Academy of Pediatric Dentistry ${ }^{18}$ (2001) recommends that the first visit of the child to the dentist should occur in the period between eruption of the first deciduous tooth and the first year of life, for prevention of future dental problems, especially early childhood caries.

Studies on this type of caries, consider several possible

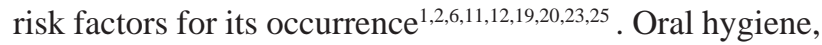
dietary habits and breastfeeding, utilization of fluoride, salivary parameters, socioeconomic level and parental educational level are the main factors cited in the literature ${ }^{1,2,6,11,12,19,20,23,25}$. The investigation of Aquino ${ }^{3}$ (1999) revealed that the industrialized food most consumed by children was milk (87.2\%), followed by sugar (66.3\%), which is introduced early (between 0 and 5 months) and in large amounts. Thickeners were also very frequent (44.7\%), especially between 6 and 11 months, being corn starch the most consumed. Thus, adoption of an improper hygiene, as well as lack of information of mothers on the oral hygiene of infants, jeopardizes the children to early occurrence of dental caries.

Ferreira and Gaiva ${ }^{11}$ (2001) stated that mothers are still unaware of the dental care needs of their infants. Thus, there is the need to establish practical actions targeted to health education and establishment of dental care to infants, on city health services ${ }^{7,8,13,24}$.

Another important information that should be provided to parents is related to the benefits of breastfeeding. Besides fulfilling the nutritional and immunological needs of the infant, breastfeeding directly influences the child's facial development, stimulating the anteroposterior mandibular growth and reinforcing the physiological neural circuit of breathing. Moreover, many studies report that when mothers breastfeed their children for more than 6 months, there is reduction in the prevalence of non-nutritive sucking habits with consequent prevention of malocclusions ${ }^{5,14,17,21}$.

The establishment of educational-preventive programs directed to infants in the public sector has been increasingly advocated, since many users of public health centers are within this age range, and often are not assisted due to poor training of professionals, as well as lack of health policies that address this type of care to the community ${ }^{4,10,23}$.

Thus, this study evaluated the efficacy of an educational-preventive program for infants in the public sector of Maringá, PR, by the analysis of the oral health of participating children.

\section{MATERIALAND METHODS}

After approval by the Institutional Review Board (protocol n. 62/03-COPEP, report n. 072/2003), 100 children of both genders, aged 1 to 6 years, in the primary dentition, registered and assisted at the same health center (Integrated Health center - NIS III Iguaçu), at the city of Maringá, PR, were examined.

The children were equally divided into two groups, Group 1 composed of 50 children attended at the dental care program for infants, and Group 2 composed of 50 children attended by spontaneous demand at the health center.

The Dental Care Program for Infants (Group I) follows an educational-preventive protocol, in which the child is inserted in the program before 1 year of age and is followed until 6 years of age. Upon inclusion of the infant, the parents and/or caretakers participate in an educational lecture that emphasizes the advantages of breastfeeding, the need of home and professional oral health maintenance measures, as well as the need to establish interceptive measures for harmful dietary, hygiene and non-nutritive sucking habits, to prevent the appearance of carious lesions and malocclusion. These orientations are reinforced to parents bimonthly, at each follow-up of the infant, when plaque disclosure and mechanical plaque control is performed by the professional.

The attendance by spontaneous demand (Group II) corresponds to assistance without pre-established followup periods. The attendance routine includes preventive and restorative measures. Initially, a hygienist provides information on the toothbrushing technique, followed by plaque disclosure and toothbrushing. After this procedure, the dentist performs the restorative treatment required. At completion of treatment, the child's caretakers are informed as to the importance of follow-up for oral health maintenance.

Data collection of both groups was performed by 2 dental professionals of the Health Secretariat of the city of Maringá, in charge of providing assistance to the children. This blind study was divided into two parts. The first comprised a semi-structured interview to the mothers or caretakers, using a pre-tested questionnaire including questions on the type of feeding offered, frequency and period of feeding and presence of non-nutritive sucking habits.

The second part of the study comprised intraoral clinical examination conducted by the two aforementioned dental professionals, previously calibrated (Kappa 0.6 for the $\mathrm{dmft}$ index and 0.7 for facial alterations). When the children had more than 2 years of age, examination was performed on the dental chair, and on a child dental bed before this age. All exams were performed with aid of a dental mirror and probe. Tongue depressors and artificial light were also employed. Evaluation was performed of the facial alterations (high arched palate, anterior open bite, posterior cross bite, protruded maxillary central incisors, mandibular protrusion, abnormal swallowing and mouth breathing) by visual exam; and dmft index, according to the WHO criteria, grouped by age range ${ }^{15}$. 
Data were processed and analyzed on the Stat Statistic software. Comparisons of caries prevalence between the studied groups were made using Mann-Whitney test $(\mathrm{p}<0.05)$. In all other comparisons chi-square test was applied $(\mathrm{p}<0.05)$.

\section{RESULTS}

Lower mean dmft index and a higher percentage of cariesfree children were observed for Group I compared to Group II (Table 1), and the difference was statistically significant $(\mathrm{p}<0.05)$.

Concerning the presence of non-nutritive sucking habits (finger, dummy, diaper and others), the children in Group I presented a prevalence of $47 \%$, compared to $67 \%$ for Group II, which was a statistically significant difference $(\mathrm{p}<0.05)$. When the caretakers were questioned on the type of habit presented by the child, it was noticed that the dummy was more cited for both groups (GI = 38.7\% and GII 62.5\%). This

TABLE 1- Mean of dmft index and percentage of cariesfree children in the study sample

\begin{tabular}{lll}
\hline Groups (N) & Dmft* (( $)$ SD) $^{*}$ & caries-free* \\
\hline Group I (50) & $0.2^{\mathrm{a}}(0.72)$ & $88 \%^{\mathrm{a}}$ \\
Group II (50) & $3.0^{\mathrm{b}}(3.39)$ & $57 \%^{\mathrm{b}}$ \\
\hline
\end{tabular}

* Means followed by different letters in each column and group are significantly different $(p<0.05)$ study observed that only $24.08 \%$ of children in Group I made use of dummy after 3 years of age, compared to $41.6 \%$ in Group II (Table 2).

A considerable part of children examined received breastfeeding up to two years of age (GI $=24.48 \%$ and GII $=$ 20.83\%), as demonstrated in Table 3. Utilization of the baby bottle is also an important habit, since the study revealed that this is routinely adopted by mothers in both groups, with a relatively high frequency $(\mathrm{GI}=89.8 \%$ and $\mathrm{GII}=87.5 \%)$, with no statistical difference between them when analyzed by the chi-square test $(\mathrm{p}<0.05)$.

An important finding of the study was related to facial alterations, since the clinical examination revealed that $81.6 \%$ of children in Group I and 52\% in Group II did not present facial alterations, with a statistically significant difference between groups $(\mathrm{p}<0.05)$. When alterations were individually analyzed, it was possible to observe that the most frequent were high arched palate, anterior open bite and mouth breathing, as displayed in Figure 1.

\section{DISCUSSION}

The challenge to work with health promotion in the public sector, especially with infants, has called the attention of several investigators involved with health education. According to Ferreira and Gaiva ${ }^{10}$ (2001) there is the need to establish practical actions directed to health education, especially in the field of dentistry, in public health centers, besides establishment of the dental care for infants. In the opinion of Silva, et al. ${ }^{22}$ (2001), preventive measures for infants would prevent the appearance of early childhood

TABLE 2- Duration of the habit of dummy sucking among the children in the study sample

\begin{tabular}{lllll}
\hline Duration of the habit & Group I & N & Group II & N \\
\hline Less than 6 months & $4.08 \%$ & 02 & $6.25 \%$ & 03 \\
6 to 12 months & $2.02 \%$ & 01 & $4.13 \%$ & 02 \\
12 to 24 months & $6.12 \%$ & 04 & $4.10 \%$ & 02 \\
24 to 36 months & $10.10 \%$ & 05 & $16.06 \%$ & 08 \\
Persistence of the habit & $24.08 \%$ & 13 & $21.66 \%$ & 14 \\
Absence of the habit & $53.6 \%$ & 25 & $27.8 \%$ & \\
\hline
\end{tabular}

TABLE 3- Period of breastfeeding among the children in the study sample

\begin{tabular}{lllll}
\hline Period of breastfeeding & Group I & N & Group II & N \\
\hline Less than 6 months & $32.65 \%$ & 16 & $33.33 \%$ & 17 \\
6 months to 1 year & $28.57 \%$ & 15 & $29.16 \%$ & 16 \\
1 to 2 years & $24.48 \%$ & 11 & $20.83 \%$ & 09 \\
More than 2 years & $8.16 \%$ & 04 & $6.25 \%$ & 03 \\
Does not know & $4.08 \%$ & 02 & $4.18 \%$ & 02 \\
Did not receive & $2.06 \%$ & 02 & $6.25 \%$ & 03 \\
\hline
\end{tabular}


caries, an impairing and painful condition, whose treatment is long, costly and stressing for both children and parents, and professional, who has the difficult task to reestablish the oral health condition.

The dental care program for infants was created following the world tendency of establishment of oral health promotion measures as early as possible, searching for improvement in the health conditions of children attending the health center in the city of Maringá, PR. Infants are included in the program until one year of age, so that followup may be really early, allowing introduction of proper diet and hygiene habits by the parents, after professional health orientation. The great challenge is to work with a population that usually does not receive any type of care in the center, as well as stimulate the children's caretakers as to the importance of regular attendance to the program, encouraging them to perform the preventive measures routinely at home. Thus, some children are still not regularly taken to preventive follow-up by the parents, present dental caries and then attend the health center only when the need of restorative treatment is noticed.

The present study revealed that, 5 years after establishment of the dental care program for infants, there was improvement in the oral conditions of children participating in the program. The caries index (dmft) of 0.2 presented by the children attending the preventive dental care program to infants (Group I) was significantly lower than the index of 3.0 of children assisted by spontaneous demand (Group II) (Table 1), which confirms reports in the literature $^{8,13,23,24}$ in which the authors highlight the importance to begin oral health follow-up as early as possible, establishing conditions for oral health maintenance. Concerning the percentage of caries-free children, Group I presented $88 \%$ compared to $57 \%$ in Group II, which further reveals the larger need of restorative treatment in the group not attending a preventive program. Within this context, it is important to mention the limitation of restorative procedures, since according to Tinanoff, et al. ${ }^{23}$ (2002), infants with early childhood caries would have difficult access to dental treatment in public health centers, especially due to poor training of health professionals to deal with this type of alteration. Moreover, the cost of prevention for the health center is significantly lower.

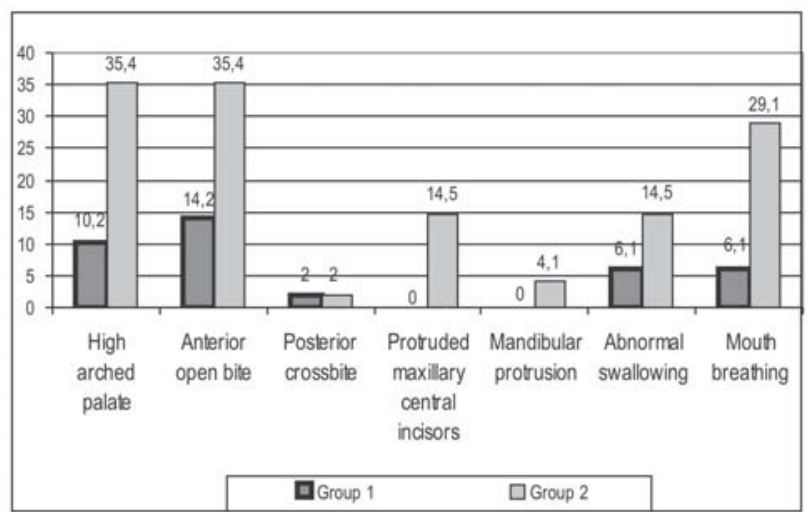

FIGURE 1- Prevalence of facial alterations in the children examined, expressed as percentages
Breastfeeding is a relevant factor in the child's development as a whole, stimulating the anteroposterior mandibular growth and reinforcing the physiological neural circuit of breathing, especially in the first six months of age, preventing the occurrence of malocclusion ${ }^{5,17}$. The study groups clearly demonstrate the importance of a multidisciplinary team in the health center, to guide, stimulate and follow mothers as to breastfeeding. It was noticed that most children examined received breastfeeding.

On the other hand, the study demonstrated that utilization of the bottle by children seems to be a common option, which is often adopted together with breastfeeding 9 . According to Barros, et al. ${ }^{6}$ (2001), a harmful aspect related to children fed by the bottle is the utilization of the bottle to sleep, leading the child to fall asleep before oral hygiene is performed, jeopardizing the child to early childhood caries.

Another important aspect in early dental care programs is the stimulation and orientation of mothers to reduce the incorporation of non-nutritive sucking habits, including dummy sucking. The study revealed that the sucking habit was more frequently present in Group II. In this same group, there was a long period before the child abandoned the habit, since $41.6 \%$ still presented the habit after 3 years of age. These data are in agreement with the study of Oliveira ${ }^{14}$ (1995), who observed presence of harmful habits, especially dummy sucking, in $48 \%$ of 3 -year-old children. This author concluded that harmful habits are more prevalent at 3 years and are reduced with the increase in age, reaching $16 \%$ at 6 years of age.

The present study demonstrated that incorporation and maintenance of non-nutritive sucking habits, frequently assigned to dummy sucking, would induce facial alterations at an early age, being able to interfere with the normal facial pattern in case it is not abandoned. The best outcome observed for Group I (Figure 1) as to the prevalence of facial alterations may be assigned to the routine follow-up, encouraging the child to abandon this practice, as well as orientation to the mothers, therefore preventing malocclusion, since significant alterations were observed in the facial pattern, such as open bite, high arched palate and abnormal swallowing, especially for Group II, for which dental care does not prioritize the education of mothers and children.

Reported data on the importance of early interceptive work for non-nutritive sucking habits reinforce the findings of many studies in the literature ${ }^{5,16,21}$ that address the importance of presence of a dental professional in programs for pregnant women and for infants, to provide this information before facial alterations are established, leading to damages in the child's normal development and requiring clinical care, most often unavailable in the public sector. If the dental care is provided after the habit is established, it should be abandoned until 3 years of age, when the pattern of neuromuscular contraction becomes mature and malocclusion may be perpetuated by the abnormal function established ${ }^{14,16}$.

Thus, considering the present findings, oral health promotion measures for infants assisted in the public sector 
are viable and fundamental to meet the demand of an age range that does not receive dental care and follow-up.

\section{CONCLUSION}

Based on the results achieved, it was concluded that the early dental care program, focused on educational and preventive actions, presented children with lower caries index, presence of non-nutritive sucking habits and prevalence of facial alterations when compared to children assisted by spontaneous demand.

\section{REFERENCES}

1- Al Ghanim NA, Adenubi JO, Wyne AA, Khan NB. Caries prediction model in pre-school children in Riyadh Saudi Arabia. Int J Paediatr Dent. 1998;8(2):115-22.

2- Alaluusua S, Malmivirta R. Early plaque accumulation - a sign for caries risk in young children. Community Dent Oral Epidemiol. 1994;22(5):273-6.

3- Aquino RC. Alimentos industrializados na dieta das crianças do município de São Paulo. São Paulo; 1999 [Dissertação Mestrado Faculdade de Nutrição da USP].

4- Baldani MHP, Lopes CML, Kriger L, Matsuo T. A odontologia para bebês no estado do Paraná, Brasil - Perfil do programa de atenção precoce à saúde bucal. J Bras Odontopediatr Odontol Bebe. 2003;6(31):210-6.

5- Baldrighi SEZM, Pinzam A, Zwicker CVD, Michelini CR, Barros DR, Elias F. A importância do aleitamento natural na prevenção de alterações miofuncionais e ortodônticas. Rev Dent Press Ortondon Ortoped Facial. 2001;6(5):111-21.

6- Barros SG, Alves AC, Pugliese LS, Reis SRA. Contribuição ao estudo da cárie dentária em crianças de 0-30 meses. Pesqui Odontol Bras. 2001;15(3):215-22.

7- Bengtson NG, Bengston AL, Bengston CRG, Pinheiro SL, Cichello LRD. Educação e higiene bucal de bebês: dispositivos e escovas dentais do mercado brasileiro. J Bras Odontopediatr Odontol Bebe. 2002;5(24):154-62

8- Bijella MFTB. A importância da educação em saúde bucal nos programas preventivos para crianças. J Bras Odontopediatr Odontol Bebe. 1999;2(6):127-31.

9- Brasil. Instituto Nacional de Alimentação e Nutrição. Instituto Materno-Infantil de Pernambuco. 2a Pesquisa Estadual de saúde e Nutrição. Pernambuco: INAN, IMIP; 1998.

10- Ferreira ARC, Gaiva MAM. Atenção odontológica para bebês: percepção de um grupo de mães. J Bras Odontopediatr Odontol Bebe. 2001;4(22):485-9.

11- Fraiz FC, Walter LRF. O comportamento infantil durante a higiene bucal domiciliar e alguns fatores associados à cárie. J Bras Odontopediatr Odontol Bebe. 2001;4(21):398-404.

12- Holst A, Martensson I, Laurin M. Identification of caries risk children and prevention of caries in pre-school children. Swed Dent J. 1997;21(5):185-91.
13- Medeiros UV, Souza MIC, Fonseca CT. Prevalência de cáries em pacientes bebês. J Bras Odontopediatr Odontol Bebe. 1998;1(3):2334.

14- Oliveira PMLC. Prevalência da mordida aberta anterior em crianças na faixa etária de 3 a 6 anos. São Paulo; 1995. [Dissertação Mestrado - Faculdade de Odontologia da USP].

15- Organização Mundial de Saúde. Levantamento epidemiológico básico de saúde bucal: manual de instruções. São Paulo: Ed. Santos; 1991.

16- Pastor IMO, Franco FCM, Leite K. O Uso da Chupeta Implicações no Desenvolvimento Infantil. Rev. Fac Odontol Univ Fed Bahia. 2000;20:82-7.

17- Pastor I, Montanha K. Amamentação natural no desenvolvimento do sistema estomagnático. Rev. Odontopeditr. 1994;3(4):185-91.

18- Policy on the dental home. Pediatr Dent. 2003;2(7):12.

19- Roeters J, Burgersdijk R, Truin GJ, Van’t Hof M. Dental caries and its determinants in 2-to-5year-old children. ASDC J Dent Child. 1995;62(6):401-8

20- Santos AP, Soviero VM. Caries prevalence and risk factors among children aged 0 to 36 months. Pesqui Odontol Bras. 2002;16(3): 203-8.

21- Serra-Negra JMC, Pordeus IA, Rocha Jr JF. Estudo da associação entre aleitamento, hábitos bucais e maloclusões. Rev Odontol Univ São Paulo. 1997;11(2):79-86.

22- Silva SMB, Oliveira FS, Pereira Jr ES, Machado MAAM. Cárie precoce na infância: relato clínico. J Bras Odontopediatr Odontol Bebê. 2001;4(22):490-6.

23- Tinanoff N, Kanellis MJ, Vargas CM. Current understanding of the epidemiology mechanisms, and prevention of dental caries in preschool children. Pediatr Dent 2002;24(6):543-51.

24- Walter LRF, Nakama L. Pacientes de alto índice de cárie x pacientes baixo risco. Qual a conduta? In: Bottino MA, Feller C. Atualização na clínica odontológica. São Paulo: Artes Médicas; 1992. p. 251-7.

25- Wennhall I, Matsson L, Schroder U, Twetman S. Caries prevalence in 3-year-old children living in a low socio-economic multicultural urban area in southern. Sweden Dent J. 2002;26(4):16772 